\title{
Effects of dietary energy and protein levels on reproductive performance in gestating sows and growth of their progeny
}

\author{
Lin Hu Fang ${ }^{1}$, Ying Hai Jin², Jae Hark Jeong ${ }^{1}$, Jin Su Hong ${ }^{1}$, Woo Lim Chung ${ }^{1}$ and Yoo Yong Kim ${ }^{1 *}$ \\ ${ }^{1}$ School of Agricultural Biotechnology, and Research Institute of Agriculture and Life Sciences, Seoul National University, Seoul 08826, Korea \\ ${ }^{2}$ Department of Animal Science, Yanbian University, Jilin Sheng 133000, China
}

\begin{abstract}
This experiment was conducted to evaluate the effect of dietary energy and crude protein (CP) levels on reproductive performance, litter performance, milk quality, and blood profiles in gestating sows. A total of 59 multiparous sows (Yorkshire $\times$ Landrace) with similar body weights (BW), backfat thickness (BF), and parity were assigned to one of six treatments with 9 or 10 sows per treatment using a $2 \times 3$ factorial arrangement and completely randomized design. The first factor was two levels of dietary metabolizable energy (ME) density $(13.40$ or $13.82 \mathrm{MJ} / \mathrm{kg})$ and the second factor was three dietary protein levels based from 35 day in gestating phases $(10.5 \%, 12 \%$, and $13.5 \%)$. Backfat thickness change in lactating sows decreased linearly as CP level increased $(p=0.03)$. Increased energy level in the gestating sow diet tended to increase the total number of piglets born $(p=0.07)$, but piglet weight decreased $(p=0.02)$. Dietary CP level had a negative effect on colostrum quality. Casein, protein, total solid, and solids-not-fat concentrations decreased linearly and lactose level increased linearly as CP level in the gestating sow diet increased (casein\%: $p=0.03$; protein $\%: p=0.04$; lactose $\%: p=0.06$; total solids: $p=0.03$; solid-not-fat: $p=0.03$, respectively). However, improving ME by $0.42 \mathrm{MJ} / \mathrm{kg}$ had no significant effect on the chemical composition of sow colostrum. There were no significant differences in blood glucose concentration in gestating sows when sows were fed different levels of energy during gestation, but blood glucose increased at 21 day of lactation when energy increased by $0.42 \mathrm{MJ} / \mathrm{kg}(p=0.04)$. Blood urea nitrogen concentration increased linearly when dietary CP levels increased at 110 day in gestation, 24-hours postpartum, and 21 days of lactation (linear, $p<0.05, p<0.05$, and $p<0.05$, respectively), and it also increased when dietary energy increased at 110 days of gestation and 24-hours postpartum ( $p<$ 0.01 , and $p<0.01$, respectively). A gestating sow diet containing $13.82 \mathrm{MJ} / \mathrm{kg} \mathrm{ME}$ and $10.5 \% \mathrm{CP}$ can improve reproductive performance, litter performance, and colostrum quality.
\end{abstract}

Keywords: Energy, Crude protein, Reproductive performance, Litter performance, Blood profiles, Gestating sows

\footnotetext{
Received: Apr 8, 2019 Revised: Apr 26, 2019 Accepted: May 1, 2019

Corresponding author: Yoo Yong Kim, School of Agricultural Biotechnology, and Research Institute of Agriculture and Life Sciences, Seoul National University, 1 Gwanak-ro, Gwanak-gu, Seoul 08826, Korea.

Tel: +82-2-880-4801, E-mail: yooykim@snu.ac.kr

This is an Open Access article distributed under the terms of the Creative Commons Attribution Non-Commercial License (http://creativecommons.org/licenses/by$\mathrm{nc} / 4.0 /$ ) which permits unrestricted non-commercial use, distribution, and reproduction in any medium, provided the original work is properly cited.

Copyright (C) 2019 Korean Society of Animal Science and Technology.
} 


\section{Background}

Various management practices coupled with research on physiology, nutrition, genetics, animal behavior, and the environment and housing have improved reproductive efficiency in sows over the past 40 years [1]. In the swine industry, an accepted measure of reproductive performance is piglets per sow per year (PSY). Total piglets born and PSY have increased every year for more than 6 years in Europe [2]. In Korea, PSY increased by 1.5 piglets from 2011 to 2013 respectively [3], but still trails behind Europe [2]. Boyd et al. [4] reported that the increase in number of litters and milk production in recent years was due to provision of more nutrients during the normal reproductive cycle. In addition, gestating sows should be fed a diet that ensures sufficient maternal protein and fat deposition to optimize fetal growth [5]. Therefore, the nutritional requirements of gestating sows should be met to satisfy both body maintenance and fetal growth [6].

Many studies had shown that adequate energy intake during the gestation period has favorable effects on fetal growth and mammary development $[7,8]$. However, excessive energy intake in gestation can reduce feed intake during lactation [9] and have a negative effect on milk production [10].

Protein deposition affects the reproductive performance of sows [11]. Pettigrew and Yang [12] reported that high protein storage in sows influenced milk production and reproductive performance. High dietary protein intake in gestating sows was shown to improve litter weight and piglet weight [13], but had no detectable effect on mammary gland development [14]. Low-protein intake had a negative effect on lactation performance [15] and performance at next parity [16]. Other studies showed that low dietary protein intake during gestation did not affect litter size or litter birth weight, but had a detrimental influence on litter weight gain even though lactating sows were fed an adequate amount of protein $[17,18]$.

Some studies have been conducted on the energy and crude protein $(\mathrm{CP})$ requirements for gestating gilts, but few studies have focused on multiparous sows. Consequently, this experiment was conducted to evaluate the effects of dietary energy and CP levels on reproductive performance, litter performance, milk quality, and blood profiles in multiparous gestating sows.

\section{Materials and Methods}

\section{Experimental animals and housing environment}

All experimental procedures involving animals were conducted in accordance with the Animal Experimental Guidelines provided by the Seoul National University Institutional Animal Care and Use Committee (SNUIACUC; SNU-160819-9). A total of 59 multiparous sows (Yorkshire $\times$ Landrace) with body weights (BW) around $241.67 \pm 8.86 \mathrm{~kg}$ were used in this study. Each sow was kept in an individual gestation stall $(2.4 \times 0.64 \mathrm{~m})$ with a feeder and a nipple drinker. Sows (parity: 3-6) were fed $2.4 \mathrm{~kg} /$ day. On day 110 of gestation, sows were transferred into environmentally controlled farrowing rooms and placed in individual farrowing crates $(2.5 \times 1.8$ $\mathrm{m})$. Each farrowing crate was equipped with a feeder and a nipple waterer.

\section{Experimental diet, treatment, and animal management}

Experimental sows (Yorkshire $\times$ Landrace) with similar BW, backfat thickness $(\mathrm{BF})$, and parity were assigned to one of six treatments with 9 or 10 sows per treatment using a $2 \times 3$ factorial arrangement and completely randomized design. The first factor was two levels of dietary metabolizable energy (ME) density (13.40 $\mathrm{MJ} / \mathrm{kg}$ or $13.82 \mathrm{MJ} / \mathrm{kg}$ ), and the second factor was three dietary CP levels based on subdivision of gestating phases $(10.5 \%, 12 \%$, and $13.5 \%)$. All nutrients in the experimental diets met or exceeded the nutrient requirements of the NRC except ME and CP [6]. Sows in the lactating period were fed the same lactation diet. Formulae and chemical compositions of the experimental gestation and lactation diets are presented in Tables 1 and 2 .

After farrowing, sow lactation diet was restricted to $1 \mathrm{~kg}$ on the first day and gradually increased by $1 \mathrm{~kg}$ per day for the first 5 days, with no limitation for the remaining lactation period. Within 24 hours after farrowing, each sow lactated 11 or 12 healthy piglets. When an experiment sow had less than 11 piglets, cross-fostering piglets were obtained from extra sows. All piglets were processed as follows: Fe-dextran (150 ppm) injection, ears notching, and tail docking. Piglets were weaned at approximately $24 \pm 2$ days, and then sows were transferred to a gestating crate.

\section{Measurements and analysis}

Gestation and lactation period, BW (BI-2RB., BI series., CAS Co., Ltd., SEL, Korea) and BF ( $\mathrm{P}_{2}$ position, Renco Crop., Minneapolis., MN, USA) of sows were measured at day 35 and 110 of gestation, at 24 hours post-farrowing, and at day 21 of lactation. The number of piglets born alive, still born, mummified fetuses, total born, and BW were measured at 24 hours post-farrowing and at day 21 of lactation. Individual piglet weight and litter size of lactating sows were recorded postpartum and at day 21 of lactation. Weaning to estrus interval (WEI) of weaned sows was recorded after weaning, as this is an important marker of reproductive performance. Voluntary feed intake of sows was also measured during lactation.

Gestating and lactating sows were bled via the anterior vena cava. Samples were collected on days 35 and 110 of gestation, and 24 hours post-farrowing. Blood samples were collected in dispos- 
Table 1. Formulae and chemical compositions of diets in the gestation phase

\begin{tabular}{|c|c|c|c|c|c|c|}
\hline \multirow{2}{*}{ Energy CP (\%) } & \multicolumn{3}{|c|}{ ME 13.40 MJ/kg (\%) } & \multicolumn{3}{|c|}{ ME 13.82 MJ/kg (\%) } \\
\hline & 10.5 & 12 & 13.5 & 10.5 & 12 & 13.5 \\
\hline Total & 100.00 & 100.00 & 100.00 & 100.00 & 100.00 & 100.00 \\
\hline \multicolumn{7}{|l|}{ Ingredient (\%) } \\
\hline Corn & 78.81 & 74.79 & 70.72 & 76.12 & 72.20 & 68.13 \\
\hline Soybean meal & 7.02 & 11.59 & 16.14 & 7.43 & 11.99 & 16.54 \\
\hline Wheat bran & 8.02 & 8.01 & 8.04 & 8.08 & 7.99 & 8.02 \\
\hline Soy-oil & 1.62 & 1.66 & 1.71 & 3.83 & 3.85 & 3.90 \\
\hline Mono-dicalcium phosphate & 1.38 & 1.31 & 1.24 & 1.40 & 1.33 & 1.26 \\
\hline Limestone & 1.55 & 1.55 & 1.55 & 1.54 & 1.54 & 1.54 \\
\hline L-lysine, $78 \%$ & 0.31 & 0.15 & 0.00 & 0.30 & 0.15 & 0.00 \\
\hline DL-methionine, $99 \%$ & 0.04 & 0.02 & 0.00 & 0.05 & 0.03 & 0.01 \\
\hline L-threonine, 99\% & 0.15 & 0.08 & 0.00 & 0.15 & 0.08 & 0.00 \\
\hline Tryptophan, $10 \%$ & 0.50 & 0.24 & 0.00 & 0.50 & 0.24 & 0.00 \\
\hline Vit. $\operatorname{Mix}^{1)}$ & 0.10 & 0.10 & 0.10 & 0.10 & 0.10 & 0.10 \\
\hline Min. $\operatorname{Mix}^{2)}$ & 0.10 & 0.10 & 0.10 & 0.10 & 0.10 & 0.10 \\
\hline Salt & 0.30 & 0.30 & 0.30 & 0.30 & 0.30 & 0.30 \\
\hline Choline-Cl & 0.10 & 0.10 & 0.10 & 0.10 & 0.10 & 0.10 \\
\hline \multicolumn{7}{|l|}{ Chemical composition $^{3)}$} \\
\hline Metabolizable energy (MJ/kg) & 13.40 & 13.40 & 13.40 & 13.82 & 13.82 & 13.82 \\
\hline Crude protein (\%) & 10.50 & 12.00 & 13.50 & 10.50 & 12.00 & 13.50 \\
\hline Total lysine (\%) & 0.67 & 0.67 & 0.67 & 0.67 & 0.67 & 0.67 \\
\hline Total methionine (\%) & 0.24 & 0.24 & 0.24 & 0.24 & 0.24 & 0.24 \\
\hline Total threonine (\%) & 0.54 & 0.54 & 0.54 & 0.54 & 0.54 & 0.54 \\
\hline Total tryptophan (\%) & 0.14 & 0.14 & 0.14 & 0.14 & 0.14 & 0.14 \\
\hline Calcium (\%) & 0.88 & 0.88 & 0.88 & 0.88 & 0.88 & 0.88 \\
\hline Total phosphorus (\%) & 0.60 & 0.60 & 0.60 & 0.60 & 0.60 & 0.60 \\
\hline \multirow{3}{*}{\multicolumn{7}{|c|}{ 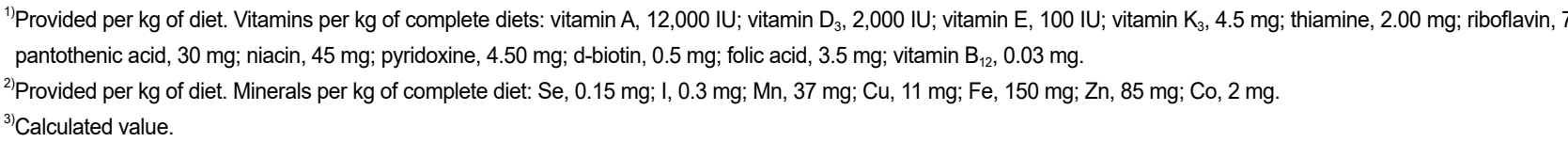 }} \\
\hline & & & & & & \\
\hline & & & & & & \\
\hline \multicolumn{7}{|c|}{$\mathrm{CP}$, crude protein; $\mathrm{ME}$, metabolizable energy. } \\
\hline
\end{tabular}

able culture tubes, and centrifuged at 1,957 $\times \mathrm{g}$ for $15 \mathrm{~min}$; the serum was harvested from all blood samples and stored at $-20^{\circ} \mathrm{C}$ until analysis. After injection of $0.3 \mathrm{~mL}$ of oxytocin (Komi oxytocin inj. Komipharm International Co., Ltd., Siheung-Si, Gyeonggi-Do, Korea), colostrum and milk samples were collected in falcon tubes (Milkoscan FT 120., FOSS, Hillerod, Demark) and stored at $-20^{\circ} \mathrm{C}$ until analysis. Concentrations of glucose and blood urea nitrogen (BUN) were analyzed at a later stage. BUN (kinetic UV assay, Roche, Germany) and glucose (enzymatic kinetic assay, Roche, Germany) concentrations were analyzed using a blood analyzer.

Colostrum and milk samples were taken from functional mammary glands of each sow at 24 hours post-farrowing and at day 21 of lactation, respectively. After collection, samples were stored in a freezer $\left(-20^{\circ} \mathrm{C}\right)$ until further analysis. Proximate analysis of colostrum and milk was conducted using the Milkoscan FT120 system
(FOSS, Hillerod, Denmark).

\section{Statistical analyses}

All collected data were analyzed using least squares mean comparisons and evaluated using general linear models (GLMs) in the statistical software package SAS (SAS Institute Inc., Cary, NC, USA). Individual sow was considered the experimental units when comparing reproductive performance, blood profiles, and milk composition among groups. Litters were used as the experimental units when assessing piglet growth. Orthogonal polynomial contrasts were used to detect linear and quadratic responses to $\mathrm{CP}$ levels when a significant $\mathrm{CP}$ effect was detected. Differences were considered significant at $p<0.05$ or highly significant at $p<0.01$, while $p \geq 0.05$ and $p<0.10$ was considered to indicate a tendency in the data. 
Table 2. Formulae and chemical compositions of diets in the lactation phase

\begin{tabular}{|c|c|}
\hline Item & $\%$ \\
\hline Ingredient (\%) & 100.00 \\
\hline Corn & 65.35 \\
\hline Soybean meal & 27.23 \\
\hline Wheat bran & 2.01 \\
\hline Soy-oil & 2.42 \\
\hline Mono-dicalcium phosphate & 1.26 \\
\hline Limestone & 1.13 \\
\hline Vit. Mix ${ }^{1)}$ & 0.10 \\
\hline Min. $M i x^{2}$ & 0.10 \\
\hline Salt & 0.30 \\
\hline Choline-Cl & 0.10 \\
\hline \multicolumn{2}{|l|}{ Chemical composition ${ }^{3)}$} \\
\hline Metabolizable energy (MJ/kg) & 13.82 \\
\hline Crude protein $(\%)$ & 17.20 \\
\hline Total lysine (\%) & 0.94 \\
\hline Total methionine (\%) & 0.28 \\
\hline Total threonine $(\%)$ & 0.70 \\
\hline Total tryptophan (\%) & 0.19 \\
\hline Calcium (\%) & 0.75 \\
\hline Total phosphorus (\%) & 0.60 \\
\hline
\end{tabular}

${ }^{11}$ Provided per kg of diet. Vitamins per kg of complete diets: vitamin A, 10,000 IU; vita$\min \mathrm{D}_{3}, 1,900 \mathrm{IU}$; vitamin $\mathrm{E}, 80 \mathrm{IU}$; vitamin $\mathrm{K}_{3}, 3.25 \mathrm{mg}$; thiamine, $2.00 \mathrm{mg}$; riboflavin, $7.0 \mathrm{mg}$; pantothenic acid, $27.5 \mathrm{mg}$; niacin, $36 \mathrm{mg}$; pyridoxine, $3.75 \mathrm{mg}$; d-biotin, 0.35 $\mathrm{mg}$; folic acid, $2.25 \mathrm{mg}$; vitamin $\mathrm{B}_{12}, 0.03 \mathrm{mg}$.

${ }^{2)}$ Provided per kg of diet. Minerals per kg of complete diet: Se, $0.15 \mathrm{mg}$; I, $0.3 \mathrm{mg} ; \mathrm{Mn}$, $37 \mathrm{mg}$; Cu, $11 \mathrm{mg}$; Fe, $150 \mathrm{mg}$ Z Zn, 85 mg; Co, 2 mg.

${ }^{3)}$ Calculated value.

\section{Results and Discussion}

\section{Sow performance}

Effects of dietary energy and CP levels on performance of gestating-lactating sows are shown in Table 3. There were no significant differences in BW, BW change, $\mathrm{BF}$, average daily feed intake (ADFI), or WEI of sows among groups. However, BF change in the lactating period decreased linearly as dietary $\mathrm{CP}$ level increased $(p=0.03)$.

Long et al. [19] reported that BW gain and BW change increased when gestating gilts was fed diets with increased dietary ME (ME: 26.50-29.01 MJ/day). Numerous studies have reported similar results [18,20-21]. In this study, there were no significant differences in BW and BW loss when dietary ME was increased by $0.42 \mathrm{MJ} / \mathrm{kg}$. This discrepancy with previous studies may be due to the small difference between the two energy levels or because we used multiparous sows compared with previous studies that used first parity sows. The growth of sows during their third parity has been shown to be slower than that of first and second parity sows [22]. The current study showed that dietary $\mathrm{CP}$ levels ranging from $10.5 \%$ to $13.5 \%$ had no effect on the BW of sows, consistent with previous studies. Jang et al. [13] reported that there was no significant difference in BW when sows were fed diets with different $\mathrm{CP}$ levels (11.4\%-17.1\%). Mahan [22] also reported no differences in $\mathrm{BW}$ or BW change when CP levels were varied from $13 \%$ to $16 \%$ in the first to fifth parities.

Backfat thickness and BF change did not change when the ME in the diet of gestating sows was increased from 13.40 to 13.82 $\mathrm{MJ} / \mathrm{kg}$. Another study showed that BF changed from $17 \mathrm{~mm}$ to $21 \mathrm{~mm}$ as dietary ME was increased from 26.50 to $29.01 \mathrm{MJ}$ per day in gestating gilts [19]. Backfat thickness changes in lactating sows decreased as dietary CP level increased $(p=0.03)$. Mahan [22] and Jang et al. [13] reported a similar result; BF change in lactation decreased numerically when dietary $\mathrm{CP}$ level in gestating sows was increased.

Average daily feed intake in lactating sows and WEI were not significantly affected by dietary energy and CP levels. In general, low feed intake has a negative effect on body condition and WEI $[23,24]$ and can decrease ovulation in the next parity [25]. Long et al. [19] reported that increasing ME by $2.51 \mathrm{MJ} /$ day during gestation could reduce $\mathrm{ADFI}$ in lactation. A similar result was reported by Revell and colleagues [9]. Previous studies have reported that dietary $\mathrm{CP}$ levels during gestation have no effects on ADFI and WEI $[13,22]$.

\section{Reproductive performance and litter performance}

The effects of dietary energy and CP levels on total piglets born per litter, litter weight, litter weight gain, average BW of piglets, and average BW gain of piglets are shown in Table 4. The total number of piglets born tended to increase $(p=0.07)$ and piglet weight decreased $(p=0.02)$ when dietary energy level in the gestating sow diet was increased. A study performed more than 40 years ago demonstrated that litter size was maximized when daily ME intake was 25.12 MJ per day [26]. However, Long et al. [19] showed that sows that received 28.18 $\mathrm{MJ}$ (ME) per day give birth to more piglets that were born alive. In addition, multiparous sows require more energy than first parity sows [27]. The NRC increased the recommended dietary energy requirements for gestating sows from 1998 to 2012 [6,27]. In our study, gestating sows (parity: 3-6) with a daily intake of $33.16 \mathrm{MJ}$ of $\mathrm{ME}(13.82 \mathrm{MJ} / \mathrm{kg})$ tended to have more total born piglets than those with a daily intake of $32.15 \mathrm{MJ}$ of $\mathrm{ME}(13.40 \mathrm{MJ} / \mathrm{kg})$.

Litter weight gain was not affected by dietary energy or $\mathrm{CP}$ level. However, a diet containing $12 \%$ dietary CP during gestation was associated with greater piglet weight at 21 days $(p=0.06)$ as well as piglet weight gain $(p=0.04)$ because the number of wean- 
Table 3. Effects of dietary energy and crude protein levels on body weight, backfat thickness, weaning to estrus interval, and daily feed intake of gestating-lactating sows

\begin{tabular}{|c|c|c|c|c|c|c|c|c|c|c|}
\hline \multirow{2}{*}{ Energy CP (\%) } & \multicolumn{3}{|c|}{ ME 13.40 MJ /kg (\%) } & \multicolumn{3}{|c|}{ ME 13.82 MJ/kg (\%) } & \multirow{2}{*}{ SEM } & \multicolumn{3}{|c|}{$p$-value } \\
\hline & 10.5 & 12 & 13.5 & 10.5 & 12 & 13.5 & & ME & CP & $M \times C$ \\
\hline No. of sows & 10 & 10 & 10 & 10 & 9 & 10 & & & & \\
\hline \multicolumn{11}{|l|}{ Body weight (kg) } \\
\hline Day 35 & 244.0 & 239.1 & 239.7 & 239.9 & 239.3 & 243.0 & 2.56 & 0.98 & 0.91 & 0.85 \\
\hline Day 110 & 259.0 & 254.0 & 252.3 & 252.7 & 254.0 & 259.2 & 2.40 & 0.96 & 0.93 & 0.56 \\
\hline Change (d 35-110) & 15.0 & 14.9 & 12.6 & 12.9 & 14.7 & 16.2 & 1.67 & 0.97 & 0.91 & 0.99 \\
\hline 24 hours. postpartum & 239.6 & 233.4 & 226.2 & 230.3 & 234.4 & 243.1 & 2.57 & 0.57 & 0.97 & 0.12 \\
\hline Day 21 of lactation & 238.7 & 241.2 & 231.8 & 230.7 & 235.0 & 243.8 & 2.89 & 0.93 & 0.88 & 0.32 \\
\hline Changes (d 0-21) & 0.9 & 7.8 & 5.6 & 0.4 & 0.6 & 0.7 & 1.36 & 0.21 & 0.35 & 0.42 \\
\hline \multicolumn{11}{|l|}{ Backfat thickness (mm) } \\
\hline Day 35 & 20.2 & 20.2 & 20.2 & 21.6 & 21.8 & 20.2 & 0.76 & 0.51 & 0.90 & 0.90 \\
\hline Day 110 & 20.7 & 21.4 & 21.3 & 23.8 & 22.8 & 22.3 & 0.83 & 0.30 & 0.98 & 0.85 \\
\hline Gain (d 35-110) & 0.5 & 1.2 & 1.1 & 2.2 & 1.0 & 2.1 & 0.71 & 0.41 & 0.95 & 0.75 \\
\hline 24 hours. Postpartum & 20.2 & 18.9 & 18.7 & 23.9 & 22.2 & 20.4 & 0.84 & 0.10 & 0.47 & 0.87 \\
\hline Day 21 of lactation & 16.7 & 18.6 & 19.6 & 21.6 & 21.9 & 19.1 & 0.81 & 0.13 & 0.84 & 0.39 \\
\hline Changes $(\mathrm{d} 0-21)^{1)}$ & -3.4 & -0.3 & 0.9 & -2.3 & -0.3 & -1.3 & 0.46 & 0.73 & 0.03 & 0.31 \\
\hline Lactation ADFI (kg/d) & 6.58 & 7.20 & 6.93 & 6.49 & 6.40 & 6.93 & 0.139 & 0.37 & 0.48 & 0.48 \\
\hline WEI (d) & 4.61 & 4.61 & 4.94 & 4.72 & 4.93 & 5.00 & 0.087 & 0.37 & 0.35 & 0.82 \\
\hline
\end{tabular}

${ }^{1)}$ Linear response $(p<0.05)$ to dietary CP levels when a significant CP effect was detected.

$\mathrm{CP}$, crude protein; ME, metabolizable energy; SEM, Standard error of means; ADFI, average daily feed intake; WEI, weaning to estrus interval.

Table 4. Effects of dietary energy and crude protein levels in the diets of gestating sows on reproductive performance and litter performance

\begin{tabular}{|c|c|c|c|c|c|c|c|c|c|c|}
\hline \multirow{2}{*}{ Energy CP (\%) } & \multicolumn{3}{|c|}{ ME $13.40 \mathrm{MJ} / \mathrm{kg}(\%)$} & \multicolumn{3}{|c|}{ ME 13.82 MJ/kg (\%) } & \multirow{2}{*}{ SEM } & \multicolumn{3}{|c|}{$p$-value } \\
\hline & 10.5 & 12 & 13.5 & 10.5 & 12 & 13.5 & & ME & $\mathrm{CP}$ & $\mathrm{M} \times \mathrm{C}$ \\
\hline No. of sows & 10 & 10 & 10 & 10 & 9 & 10 & & & & \\
\hline \multicolumn{11}{|l|}{ Litter size, no. of piglets } \\
\hline Total born & 12.90 & 10.40 & 12.90 & 13.80 & 13.44 & 13.50 & 0.426 & 0.07 & 0.30 & 0.44 \\
\hline Born alive & 12.90 & 10.40 & 12.30 & 13.30 & 13.22 & 12.40 & 0.395 & 0.17 & 0.39 & 0.31 \\
\hline After cross-fostering & 11.40 & 11.80 & 11.80 & 11.50 & 11.56 & 11.88 & 0.093 & 0.81 & 0.31 & 0.75 \\
\hline No. of deaths upon weaning & $0.20^{c}$ & $0.60^{b}$ & $0.50^{\mathrm{b}}$ & $0^{d}$ & $1.00^{\mathrm{a}}$ & $0.88^{\mathrm{a}}$ & 0.508 & 0.48 & 0.03 & 0.48 \\
\hline Weaning pigs (d 21) & $11.20^{\mathrm{b}}$ & $11.20^{b}$ & $11.30^{\mathrm{ab}}$ & $11.50^{\mathrm{a}}$ & $10.56^{c}$ & $11.00^{\mathrm{bc}}$ & 0.127 & 0.43 & 0.34 & 0.31 \\
\hline \multicolumn{11}{|l|}{ Litter weight (kg) } \\
\hline At birth & 18.58 & 16.44 & 19.55 & 19.34 & 18.64 & 18.31 & 0.477 & 0.55 & 0.35 & 0.35 \\
\hline After cross-fostering & 17.41 & 19.06 & 18.96 & 17.18 & 16.66 & 17.96 & 0.289 & 0.04 & 0.23 & 0.28 \\
\hline Day 21 of lactation & 66.38 & 72.95 & 69.55 & 69.32 & 66.96 & 64.89 & 1.286 & 0.33 & 0.65 & 0.32 \\
\hline Weight gain (d 0-21, kg) & 48.97 & 53.89 & 50.59 & 52.14 & 50.30 & 46.94 & 1.200 & 0.58 & 0.53 & 0.43 \\
\hline \multicolumn{11}{|l|}{ Piglet weight (kg) } \\
\hline At birth & 1.47 & 1.62 & 1.54 & 1.41 & 1.39 & 1.41 & 0.028 & 0.02 & 0.75 & 0.31 \\
\hline After cross-fostering & 1.53 & 1.61 & 1.61 & 1.50 & 1.44 & 1.52 & 0.022 & 0.03 & 0.63 & 0.43 \\
\hline Day 21 of lactation & 5.94 & 6.51 & 6.14 & 6.02 & 6.33 & 5.86 & 0.084 & 0.41 & 0.06 & 0.63 \\
\hline Weight gain $(\mathrm{d} 0-21, \mathrm{~kg})^{1)}$ & 4.41 & 4.90 & 4.53 & 4.53 & 4.89 & 4.34 & 0.080 & 0.81 & 0.04 & 0.71 \\
\hline
\end{tabular}


ing pigs was lower than in other treatments. Although there was no significant difference in milk quality, a $10.5 \% \mathrm{CP}$ diet resulted in the best colostrum quality. The number of piglet deaths upon weaning was lower in sows that received a diet with $10.5 \% \mathrm{CP}$. This is consistent with the results of Mahan [22] who reported that the number of piglet deaths increased as dietary $\mathrm{CP}$ level was increased by $3 \%$ in gestating sows. Previous studies have reported that low dietary protein intake in gestating sows did not affect litter size or litter birth weight, but had a detrimental influence on litter weight gain even though lactating sows were fed an adequate protein level $[17,18]$. Results in this study are not consistent with those of previous studies; this may be because a CP level of $10.5 \%$ is sufficient for gestating sows.

\section{Milk composition}

The effects of dietary energy and CP levels on the chemical composition of colostrum and milk in sows are shown in Table 5. There were no significant differences in milk quality on day 21 of lactation according to dietary gestation energy level (ME: 13.40-13.82 $\mathrm{MJ} / \mathrm{kg}$ ) or CP level (10.5\%-13.5\%), but casein $(p=0.03)$, protein ( $p$ $=0.04)$, total solids $(p=0.03)$ and solids-not-fat $(p=0.03)$ concentration increased linearly and lactose $(p=0.06)$ level tended to decrease linearly in colostrum when decreasing $\mathrm{CP}$ level in gestating sow diets. The high protein content in colostrum is due to presence of immunoglobulins [28]. Immunoglobulins content was increased when protein content increased in colostrum [29]. The sow prioritizes protein content in colostrum and milk if the protein content in the feed is scarce, by metabolizing body reserves, which indicates that protein is extremely important to the piglets. The newborn piglet depends on colostrum to ingest immunoglobulins because of the structure of the pig placenta does not allow immunoglobulins to pass over from the sow to the fetus [30]. The ingestion is needed in order to be able to obtain passive immunity. A piglet that does not ingest colostrum will consequently not only be more sensitive to infections, but also to starvation and hypothermia.

The findings of this study demonstrate that decreasing $\mathrm{CP}$ level in gestating sow diet increased casein, protein, total solids and solids-not-fat linearly of colostrum. Therefore, low CP level in gestating sow diet found better colostrum quality. However, other researchers did not find any effect on colostrum composition when gilts were feed different levels of CP in gestation diets [13,22,31]. The sows reduced feed intake at the first day postpartum. It means that nutrients accumulated in the sow body are used to produce colostrum. So, the ability for catabolism of the nutrients in the body is important in farrowing sows. In this study, BF change in lactating sows decreased as gestation dietary CP level increased $(p=$ $0.03)$, and ADFI of lactating sows was not significant $(p=0.48)$. It may agree that low $\mathrm{CP}$ intake (10.5\%) in gestating sows was found higher catabolism of the body reserves to make higher quality of colostrum than high CP intake (13.5\%). However, further study is needed to clearly demonstrate a possible correlation among protein level in gestating sows diet, catabolism of the body reserves and colostrum composition.

Table 5. Effects of dietary energy and crude protein levels in the diets of gestating sows on chemical compositions of the colostrum and milk of sows

\begin{tabular}{|c|c|c|c|c|c|c|c|c|c|c|}
\hline \multirow{2}{*}{ Energy CP (\%) } & \multicolumn{3}{|c|}{ ME $13.40 \mathrm{MJ} / \mathrm{kg}(\%)$} & \multicolumn{3}{|c|}{ ME 13.82 MJ/kg (\%) } & \multirow{2}{*}{ SEM } & \multicolumn{3}{|c|}{$p$-value } \\
\hline & 10.5 & 12 & 13.5 & 10.5 & 12 & 13.5 & & ME & $\mathrm{CP}$ & $M \times C$ \\
\hline \multicolumn{11}{|l|}{24 hours postpartum (\%) } \\
\hline Casein $^{1)}$ & 9.83 & 7.37 & 5.46 & 8.35 & 8.06 & 5.67 & 0.550 & 0.85 & 0.03 & 0.66 \\
\hline Fat & 6.63 & 6.71 & 5.38 & 6.73 & 3.45 & 4.99 & 0.497 & 0.24 & 0.34 & 0.33 \\
\hline Protein ${ }^{1)}$ & 13.31 & 9.83 & 7.30 & 11.28 & 10.85 & 7.47 & 0.767 & 0.85 & 0.04 & 0.67 \\
\hline Lactose $^{1)}$ & 3.42 & 4.08 & 4.28 & 3.65 & 3.95 & 4.54 & 0.146 & 0.68 & 0.06 & 0.82 \\
\hline Total solids ${ }^{1)}$ & 27.16 & 23.36 & 19.14 & 24.77 & 21.10 & 18.98 & 1.042 & 0.41 & 0.03 & 0.87 \\
\hline Solids-not-fat ${ }^{1)}$ & 16.94 & 13.91 & 11.75 & 14.98 & 14.96 & 12.05 & 0.641 & 0.86 & 0.03 & 0.56 \\
\hline \multicolumn{11}{|l|}{ Day 21 of lactation (\%) } \\
\hline Casein & 4.29 & 4.68 & 4.58 & 4.10 & 4.62 & 4.54 & 0.086 & 0.58 & 0.11 & 0.93 \\
\hline Fat & 5.95 & 7.08 & 6.79 & 5.67 & 6.51 & 6.66 & 0.245 & 0.53 & 0.23 & 0.93 \\
\hline Protein & 4.86 & 5.19 & 5.21 & 4.54 & 5.24 & 5.00 & 0.122 & 0.53 & 0.24 & 0.83 \\
\hline Lactose & 6.04 & 6.37 & 6.11 & 6.50 & 6.12 & 6.38 & 0.067 & 0.22 & 0.98 & 0.10 \\
\hline Total solids & 18.61 & 20.19 & 19.76 & 18.34 & 19.42 & 19.46 & 0.321 & 0.50 & 0.24 & 0.94 \\
\hline Solids-not-fat & 11.02 & 11.44 & 11.37 & 10.87 & 11.42 & 11.34 & 0.085 & 0.69 & 0.11 & 0.94 \\
\hline
\end{tabular}

${ }^{11}$ Linear response $(p<0.05)$ to dietary CP levels when a significant CP effect was detected.

$\mathrm{ME}$, metabolizable energy; CP, crude protein; SEM, Standard error of means. 


\section{Blood profiles of sows}

The effects of dietary energy and CP levels on blood glucose and BUN concentration during the gestation-lactation period are shown in Table 6. There was no significant difference in blood glucose concentration in gestating when sows were fed different levels of $\mathrm{ME}$ during gestation, but blood glucose concentration increased at 21 day of lactation when ME levels increased by $0.42 \mathrm{MJ} / \mathrm{kg}(p$ $=0.04$ ). In this study, the treatment with $13.82 \mathrm{MJ} / \mathrm{kg}$ of dietary $\mathrm{ME}$ showed lower $\mathrm{ADFI}$ than $13.40 \mathrm{MJ} / \mathrm{kg}$ of $\mathrm{ME}$, and it had an agreement with Cozler et al. [32] who reported blood glucose concentration had a negative effect on ADFI.

Blood urea nitrogen is one of the indicator of protein utilization. A low BUN level is associated with improved protein synthesis and reduced amino acid oxidation, which can lead to reduced availability of ammonia [33]. Fuller et al. [34] reported that CP synthesis was improved by carbohydrate intake. In addition, increasing total $\mathrm{N}$ intake could increase BUN concentration [35]. In this study, BUN concentration increased linearly with dietary CP level at 110 day of gestation, 24 hours postpartum and 21 day of lactation $(p<$ $0.05, p<0.05$, and $p<0.05$, respectively), and also increased with an increase in dietary energy at day 110 of gestation and 24 hours postpartum ( $p<0.01$, and $p<0.01$, respectively). Results of the study by Jang et al. [13] are consistent with the current results, they reported that plasma urea nitrogen concentration increased when dietary $\mathrm{CP}$ level in gestating sows was increased.

\section{Conclusion}

Total number of piglets born increased with an increase in daily dietary ME of $0.42 \mathrm{MJ} / \mathrm{kg}(13.40 \mathrm{MJ} / \mathrm{kg}$ to $13.42 \mathrm{MJ} / \mathrm{kg})$ in gestating sows. Backfat thickness changes and colostrum quality decreased and piglet death during lactation and BUN level increased as dietary CP level increased (10.5\%-13.5\%). A gestating sow diet containing $13.82 \mathrm{MJ} / \mathrm{kg} \mathrm{ME}$ and $10.5 \% \mathrm{CP}$ can improve reproductive performance, litter performance, and colostrum quality.

\section{Competing interests}

No potential conflict of interest relevant to this article was reported.

\section{Funding sources}

This work was carried out with the support of the Cooperative Research Program for Agriculture Science \& Technology Development (Project No. PJ011617), Rural Development Administration, Korea.

\section{Acknowledgements}

Not applicable.

\section{Availability of data and material}

Upon reasonable request, the datasets of this study can be available from the corresponding author.

\section{Authors' contributions}

Conceptualization: Kim YY.

Data curation: Fang LH, Jeong JH.

Formal analysis: Fang LH, Jeong JH.

Methodology: Chung WL, Jeong JH.

Software: Jeong JH, Hong JS.

Validation: Jin YH, Chung WL.

Investigation: Kim YY, Hong JS.

Writing - original draft: Fang LH, Jeong JH.

Writing - review \& editing: Kim YY, Hong JS.

Table 6. Effects of dietary energy and crude protein levels on blood profiles of sows

\begin{tabular}{|c|c|c|c|c|c|c|c|c|c|c|}
\hline \multirow{2}{*}{ Energy CP (\%) } & \multicolumn{3}{|c|}{ ME $13.40 \mathrm{MJ} / \mathrm{kg}(\%)$} & \multicolumn{3}{|c|}{ ME 13.82 MJ/kg (\%) } & \multirow{2}{*}{ SEM } & \multicolumn{3}{|c|}{$p$-value } \\
\hline & 10.5 & 12 & 13.5 & 10.5 & 12 & 13.5 & & ME & $\mathrm{CP}$ & $M \times C$ \\
\hline \multicolumn{11}{|l|}{ Glucose (mmol/L) } \\
\hline Day 35 & \multicolumn{6}{|c|}{4.03} & - & - & - & - \\
\hline Day 110 & 4.39 & 4.49 & 4.39 & 4.13 & 4.43 & 4.59 & 0.055 & 0.82 & 0.28 & 0.25 \\
\hline 24 hours postpartum & 5.60 & 5.59 & 5.92 & 5.19 & 5.97 & 5.65 & 0.128 & 0.33 & 0.95 & 0.13 \\
\hline Day 21 of lactation & 4.54 & 4.05 & 4.31 & 4.55 & 4.58 & 4.52 & 0.064 & 0.04 & 0.27 & 0.22 \\
\hline \multicolumn{11}{|l|}{$\mathrm{BUN}(\mathrm{mmol} / \mathrm{L})$} \\
\hline Day 35 & \multicolumn{6}{|c|}{3.68} & - & - & - & - \\
\hline Day $110^{1)}$ & 2.46 & 2.70 & 3.50 & 3.25 & 3.29 & 3.33 & 0.109 & $<.01$ & 0.01 & 0.05 \\
\hline 24 hours postpartum ${ }^{L}$ & 2.30 & 2.26 & 4.00 & 2.90 & 3.61 & 3.68 & 0.176 & $<.01$ & $<.01$ & $<.01$ \\
\hline Day 21 of lactation ${ }^{\mathrm{L}}$ & 5.93 & 7.46 & 7.61 & 7.38 & 7.06 & 6.94 & 0.159 & 0.24 & 0.02 & $<.01$ \\
\hline
\end{tabular}




\section{Ethics approval and consent to participate}

This article does not require IRB/IACUC approval because there are no human and animal participants.

\section{ORCID}

Lin Hu Fang
Ying Hai Jin
Jae Hark Jeong
Jin Su Hong
Woo Lim Chung
Yoo Yong Kim
https://orcid.org/0000-0002-3617-7583 https://orcid.org/0000-0002-6925-3183 https://orcid.org/0000-0001-9611-3787 https://orcid.org/0000-0002-3401-3024 https://orcid.org/0000-0003-1724-9358 https://orcid.org/0000-0001-8121-3291

\section{References}

1. Kraeling RR, Webel SK. 2015. Current strategies for reproductive management of gilts and sows in North America. J Anim Sci Biotech. 2015;6:3.

2. AHDB Pork. 2015. The BPEX yearbook 2014-2015. https:// pork.ahdb.org.uk/media/73777/bpex-yearbook-2015.pdf. Accessed 21 Sep 2018.

3. Choe JH, Yang HS, Lee SH, Go GW. Characteristics of pork belly consumption in South Korea and their health implication. J Anim Sci Technol. 2015;57:22.

4. Boyd RD, Touchette KJ, Castro GC, Johnston ME, Lee KU, Han IK. Recent advances in amino acid and energy nutrition of prolific sows. Asian-Aust J Anim Sci. 2000;13:1638-52.

5. Ji F, Wu G, Blanton JR Jr, Kim SW. Changes in weight and composition in various tissues of pregnant gilts and their nutritional implications.J Anim Sci. 2005;83:366-75.

6. Committee on Nutrient Requirements of Swine, National Research Council. Nutrient requirements of swine. 10th ed. Washington, DC: National Academy Press; 1998.

7. Trottier NL, Johnston LJ. Feeding gilts during development and sows during gestation and lactation. In: Lewis AJ, Southern LL, editors. Swine nutrition. 2nd ed. New York, NY: CRC Press; 2001.p. 725-69.

8. Cerisuelo A, Baucells MD, Gasa J, Coma J, Carrion D, Chapinal $\mathrm{N}$, et al. Increased sow nutrition during midgestation affects muscle fiber development and meat quality, with no consequences on growth performance. J Anim Sci. 2009;87:72939.

9. Revell DK, Williams IH, Mullan BP, Ranford JL, Smits RJ. Body composition at farrowing and nutrition during lactation affect the performance of primiparous sows: I. Voluntary feed intake, weight loss, and plasma metabolites. J Anim Sci. 1998;76:1729-37.

10. Messias de Braganca M, Mounier AM, Prunier A. Does feed restriction mimic the effects of increased ambient temperature in lactating sows. J Anim Sci. 1998;76:2017-24.

11. Kim SW, Hurley WL, Wu G, Ji F. Ideal amino acid balance for sows during gestation and lactation. J Anim Sci. 2009;87:E123-32.

12. Pettigrew JE, Yang H. Protein nutrition of gestating sows. J Anim Sci. 1997;75:2723-30.

13. Jang YD, Jang SK, Kim DH, Oh HK, Kim YY. Effects of dietary protein levels for gestating gilts on reproductive performance, blood metabolites and milk composition. Asian-Aust J Anim Sci. 2014;27:83-92.

14. Kusina J, Pettigrew JE, Sower AF, White ME, Crooker BA, Hathaway MR. Effect of protein intake during gestation and lactation on lactational performance of the primiparous sow. J Anim Sci. 1999;77:931-41.

15. Head RH, Williams IH. Mammogenesis is influenced by the nutrition of gilts during pregnancy. In: Manipulating pig production III. Batterham ES, editor. Aust Pig Sci Assoc; 1991. p. 33.

16. Svajgr AJ, Hammell DL, DeGetter MJ, Hays VW, Cromwell GL, Dutt RH. Reproductive performance of sows on a protein-restricted diet.J Reprod Fert. 1972;30:455-8.

17. Baker DH, Becker DE, Jensen AH, Harman BG. Reproductive performance and progeny development in swine as influenced by protein restriction during various portions of gestation.J Anim Sci. 1970;31:526-30.

18. Kusina J, Pettigrew JE, Sower AF, White ME, Crooker BA, Hathaway MR. Effect of protein intake during gestation and lactation on the lactational performance of primiparous sows.J Anim Sci. 1999;77:931-41.

19. Long HF, Ju WS, Piao LG, Kim YY. Effect of dietary energy levels of gestating sows on physiological parameters and reproductive performance. Asian-Aust J Anim Sci. 2010;23:1080-8.

20. Dourmad JY. Effect of feeding level in the gilt during pregnancy on voluntary feed intake during lactation and changes in body composition during gestation and lactation. Livest Prod Sci. 1991;27:309-19.

21. Averette GL, See MT, Hansen JA, Sutton D, Odle J. The effects of dietary fat sources, levels, and feeding intervals on pork fatty acid composition. J Anim Sci. 2002;80:1606-15.

22. Mahan DC. Relationship of gestation protein and feed intake level over a five-parity period using a high-producing sow genotype.J Anim Sci. 1998;76:533-41.

23. King RH, Williams HI. The effects of nutrition on the reproductive performance of first litter sows 2. Protein and energy intakes during lactation. Anim Sci. 1984;38:249-56.

24. Baidoo SK, Aherne FX, Kirkwood RN, Foxcroft GR. Effect of feed intake during lactation and after weaning on sow reproductive performance. Can J Anim Sci. 1992;72:911-7. 
25. Foxcroft GR, Aherne FX, Clowes EC, Miller H, Zak LJ. Sow fertility: the role of suckling inhibition and metabolic status. In: Ivan $\mathrm{M}$, editor. Animal science research and development: moving toward a new century. Ottawa, ON: Centre for Food and Animal Research; 1995. p. 377-93.

26. Frobish LT, Steele NC, Davey RJ. Long term effect of energy intake on reproductive performance of swine. J Anim Sci. 1973;36:293-7.

27. Committee on Nutrient Requirements of Swine, National Research Council. Nutrient requirements of swine. 11th ed. Washington, DC: National Academy Press; 2012.

28. Klobasa F, Werhahn E, Butler JE. Composition of sow milk during lactation.J Anim Sci. 1987;64:1458-66.

29. Devillers N, van Milgen J, Prunier A, Le Dividich J. Estimation of colostrum intake in the neonatal pig. Anim Sci. 2004;78:305-13.

30. Rooke JA, Sinclair AG, Edwards SA, Cordoba R, Pkiyach $\mathrm{S}$, Penny PC, et al. The effect of feeding salmon oil to sows throughout pregnancy on pre-weaning mortality of piglets. Anim Sci. 2016;73:489-500.

31. Elliott RF, Vander Noot GW, Gilbreath RL, Fisher H. Effect of dietary protein level on composition changes in sow colostrum and milk. J Anim Sci. 1971;32:1128-37.

32. Cozler YL, David C, Beaumal V, Johansen S, Dourmad JY. Effect of the feeding level during rearing on performance of large white gilts. Part 2: effect on metabolite profiles during gestation and lactation, and on glucose tolerance. Reprod Nutr Dev. 1998;38:377-90.

33. Wu G, Morris SM Jr. Arginine metabolism: Nitric oxide and beyond. Biochem J. 1998;336:1-17.

34. Fuller MF, Weekes TEC, Cadenhead A, Bruce JB. The protein-sparing effect of carbohydrate. 2. The role of insulin. $\mathrm{Br} \mathrm{J}$ Nutr. 1977;38:489-96.

35. Whang KY, Easter RA. Blood urea nitrogen as an index of feed efficiency and lean growth potential in growing-finishing swine. Asian-Aust J Anim Sci. 2000;13:811-6. 